\title{
SISTEM INFORMASI PADA SMAN 1 KAHAYAN HILIR PULANG PISAU MENGGUNAKAN
} FRAMEWORK CODEIGNITER

\author{
Rosmiati $^{1}$, M. Haris Qamaruzzaman ${ }^{2}$ \\ Teknik Informatika ${ }^{1}$ - STMIK Palangkaraya, Ilmu Komputer ${ }^{2}$ - Universitas Muhammadiyah \\ Palangkaraya \\ ${ }^{1}$ Jl. G.Obos No. 114 Palangkaraya, ${ }^{2}$ Jl. RTA. Milono Km. 1,5 Palangkaraya, Kalimantan Tengah \\ Email : fayadhah@gmail.com ${ }^{1}$, harisqamaruzzaman@yahoo.co.id ${ }^{2}$
}

\begin{abstract}
ABSTRAK
Sekolah adalah tempat pendidikan dimana siswa dan guru melakukan kegiatan belajar mengajar. SMAN 1 Kahayan Hilir Pulang Pisau dapat memberikan informasi sekolahnya kepada orang yang membutuhkan informasi khususnya orang tua siswa. Informasi sekolah yang diperoleh orang tua siswa dan masyarakat umum dengan mendatangi secara langsung ke sekolah atau orang tua siswa menanyakan informasi kepada siswa yang bersekolah pada sekolah yang dimaksud. Sehingga terbatasnya informasi dan komunikasi, khususnya antara sekolah dan orang tua siswa. Untuk membantu memudahkan siswa, orang tua dan masyarakat umum dalam kebutuhan informasi, misalnya berita terbaru yang dikeluarkan oleh pihak sekolah dan pendaftaran online. Jenis penelitian yang digunakan adalah Research and Development dan metode pengumpulan data (observasi, wawancara, dokumentasi dan studi pustaka), menerapkan metode Agile Software Development dengan menggunakan pendekatan pengembangan perangkat lunak Extreme Programming (XP) dan metode pengujian perangkat lunak menggunakan black box testing. Framework codeigniter mempercepat proses pembuatan website SMAN 1 Kahayan Hilir Pulang Pisau, karena semua class dan modul yang dibutuhkan sudah ada di dalam framework codeigniter. Hasil penelitian ini adalah sebuah aplikasi website secara online yang mempermudah pihak sekolah dalam memberikan informasi kepada pengguna (siswa, orang tua siswa serta masyarakat umum), karena dapat diakses dimana dan kapan saja oleh pengguna dengan menggunakan media komputer, laptop atau smartphone yang tentunya harus selalu terkoneksi dengan jaringan internet. Sehingga pengguna dapat dengan mudah mengetahui infomasi-informasi yang kurang jelas.
\end{abstract}

Kata Kunci : Sistem Informasi, SMAN 1 Kahayan Hilir Pulang Pisau, Website.

\section{$\underline{\text { ABSTRACT }}$}

The school is a place of education where students and teachers carry out teaching and learning activities. SMAN 1 Kahayan Hilir Pulang Pisau can provide school information to people who need parents' information. School information obtained by parents of students and the general public who will come directly to the school or parents of students asking for information from students who attend the requested school. Related to the limited information and communication, especially between schools and parents of students. To help students, parents and the general public need information, such as the latest news issued by the school and online registration. This type of research is Research and Development and data collection methods (observation, interviews, documentation and literature studies), using the Agile Software Development method by using Extreme Programming (XP) software development and device testing methods using black box testing. The codingigniter framework enhances the process of creating the SMAN 1 Kahayan Hilir Pulang Pisau website, because all the required classes and modules are already in the codeigniter framework. The results of this study are an online website application that makes it easy for schools to provide information to users (students, parents of students and the general public), can be accessed anywhere and anytime by the user using computer media, laptops or smartphones as needed to always be connected to the internet network. Unclear information.

Keywords: Information Systems, SMAN 1 Kahayan Hilir Pulang Pisau, Website. 


$$
\begin{array}{r|l}
\text { Jurnal Sains Komputer dan Teknologi Informasi } & \text { Page } \\
\text { E-ISSN: 2655-7460. Volume 2 Issue 2, Mei 2020 } & 22 \text { - } 26
\end{array}
$$

\section{PENDAHULUAN}

Perkembangan Teknologi yang semakin pesat telah memicu munculnya berbagai aplikasi baru termasuk di bidang Teknologi Informasi. Peranan teknologi informasi dalam bidang komunikasi sangatlah besar, dimana komunikasi memegang peranan penting dalam kehidupan. Salah satu teknologi informasi yang sering dibicarakan akhir-akhir ini adalah jaringan komunikasi global yang dikenal dengan sebutan internet. Internet merupakan sarana yang mampu menghubungkan pengguna (user) diberbagai tempat dunia sehingga seakan-akan tidak ada jarak antara para pengguna tersebut.

Pada perkembangnanya, teknologi informasi terutama aplikasi web yang semakin berkembang saat ini menjadikan aplikasi web sebagai salah satu wadah yang digunakan oleh banyak orang untuk memudahkan dalam mengakses informasi yang diinginkan. Selain itu, Website juga berfungsi sebagai pengelola data (basis data) berbasis web. Sehingga selain tampilan yang menarik juga menyajikan informasi yang interaktif dan komunikatif.

Dalam dunia pemrograman website, ada banyak framework yang dapat digunakan, salah satu framework yang sering digunakan oleh para developer untuk membuat website adalah framework codeigniter. Codelgniter adalah sebuah framework untuk web yang dibuat dengan format bahasa pemrograman PHP. Codelgniter dapat mempercepat proses pembuatan web, karena semua class dan modul yang dibutuhkan sudah ada dan hanya tinggal digunakan kembali pada aplikasi web yang akan dibuat dengan konsep MVC (Model View Controller), dibandingkan dengan Framework lain. Codeigniter adalah sebuah alternative bagi pengembang website yang menginginkan akses yang cepat. Karena Codeigniter hanya me-load fungsi atau library yang digunakan saja, berbeda dengan Framework lainnya yang menggunakan seluruh library walaupun library tersebut tidak digunakan. Alasan inilah yang menjadikan Codeigniter dengan akses tercepat dan ringan.

Sekolah adalah tempat pendidikan dimana siswa dan guru melakukan kegiatan belajar mengajar. SMAN 1 Kahayan Hilir Pulang Pisau dapat memberikan informasi sekolahnya kepada orang yang membutuhkan informasi khususnya orang tua siswa. Informasi sekolah yang diperoleh orang tua siswa dan masyarakat umum dengan mendatangi secara langsung ke sekolah atau orang tua siswa menanyakan informasi kepada siswa yang bersekolah pada sekolah yang dimaksud.
Sehingga terbatasnya informasi dan komunikasi, khususnya antara sekolah dan orang tua siswa.

Dari permasalahan tersebut maka penulis mencoba untuk membuat sebuah Website SMAN 1 Kahayan Hilir Pulang Pisau menggunakan Framework Codelgniter yang menyediakan informasi secara cepat, akurat guna dapat diterima.

\section{LANDASAN TEORI \\ 2.1 Website}

Menurut Rahmat Hidayat (2010:2) website atau situs dapat diartikan sebagai kumpulan halamanhalaman yang digunakan untuk menampilkan informasi teks, gambar diam atau gerak, animasi, suara, yang dan gabungan dari semuanya, baik yang bersifat statis maupun dinamis membentuk satu rangkaian bangunan yang saling terkait, yang masing-masing dihubungkan dengan jaringan-jaringan halaman.

\subsection{Codelgniter (CI)}

Menurut Septian (2011), Codelgniter adalah aplikasi open source yang berupa framework dengan model MVC (Model View Controller) untuk memangun website dinamis dengan menggunakan PHP. Codelgniter memudahkan developer untuk membuat aplikasi web dengan cepat dan mudah dibandingkan dengan membuat dari awal.

\subsection{Jquery}

Jquery merupakan suatu framework (library) Javascript yang menekankan bagaimana interaksi antara Javascript dan HTML yang akan membuat aplikasi web yang menjadi lebih menarik, baik dari sisi user-interface, proses maupun interaktivitas. Jquery pertama kali dirilis pada tahun 2006 oleh John Resig. Pada perkembangannya JQuery tidak sekedar sebagai framework javascript, namun memiliki kehandalan dan kelebihan yang cukup banyak. JQuery memiliki slogan yaitu kesederhanaan dalam penulisan code, tapi dengan hasil yang lebih banyak.

\subsection{Twitter Bootstrap}

Menurut Ridha (2003-2007:4) Twitter Bootstrap adalah sebuah alat bantu membuat tampilan halaman Website yang dapat mempercepat pekerjaan seorang pengembang Website ataupun pendesain halaman Website. Sesuai namanya, Website yang dibuat dengan alat bantu ini memiliki tampilan halaman yang sama atau mirip dengan tampilan halaman Web sesuai dengan kebutuhan.

\subsection{Perangkat Lunak Yang Digunakan}


Rosmiatí dan M.Haris Qamaruzzaman. Sistem Informasi pada Sman 1 Kahayan Hilir 2020 Pulang Pisau Menggunakan Framework Codeigniter.

Beberapa perangkat lunak yang digunakan pada penelitian ini adalah :
1) XAMPP
2) Notepad ++
3) Star Unified Modelling Language (UML)
4) Balsamiq Mockups

\section{HASIL DAN PEMBAHASAN}

Hasil dari penelitian ini adalah berupa aplikasi Website sebagai media penyampaian informasi dari pihak sekolah kepada pengguna yang terdiri dari :

\section{Halaman Menu Utama}

Pada halaman utama menampilkan berita terbaru, berita terpopuler, slideshow berita, interaktif menu, pengumuman, agenda, kelender, galeri foto dan tautan. Dapat dilihat pada gambar 1.

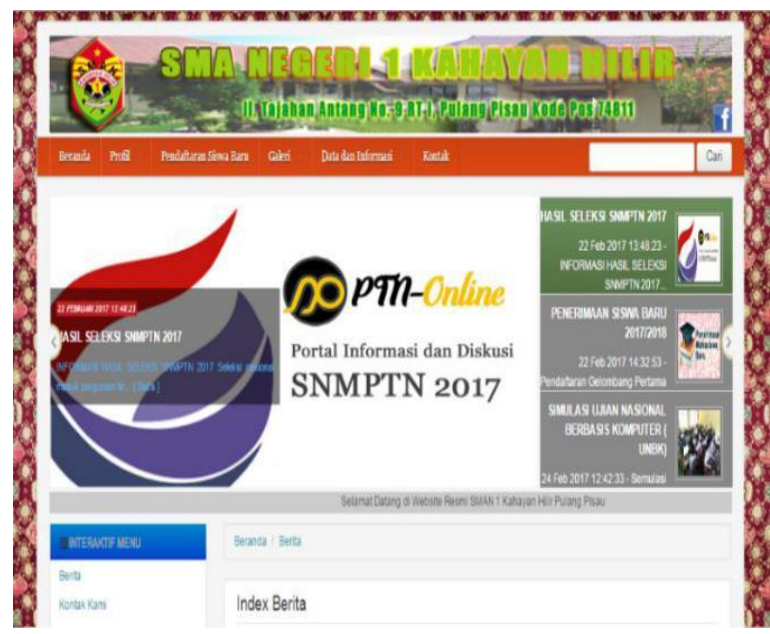

Gambar 1. Menu Huruf

\section{Menu Profil}

Pada menu profil berisi visi dan misi SMAN 1 Kahayan Hilir Pulang Pisau, sub-menu yang kedua menampilkan sejarah singkat, sub-menu yang ketiga menampilkan sarana dan prasarana, sub-menu yang keempat menampilkan biodata guru, dan sub-menu yang kelima menampilkan biodata tata usaha. Dapat dilihat pada gambar 2 .

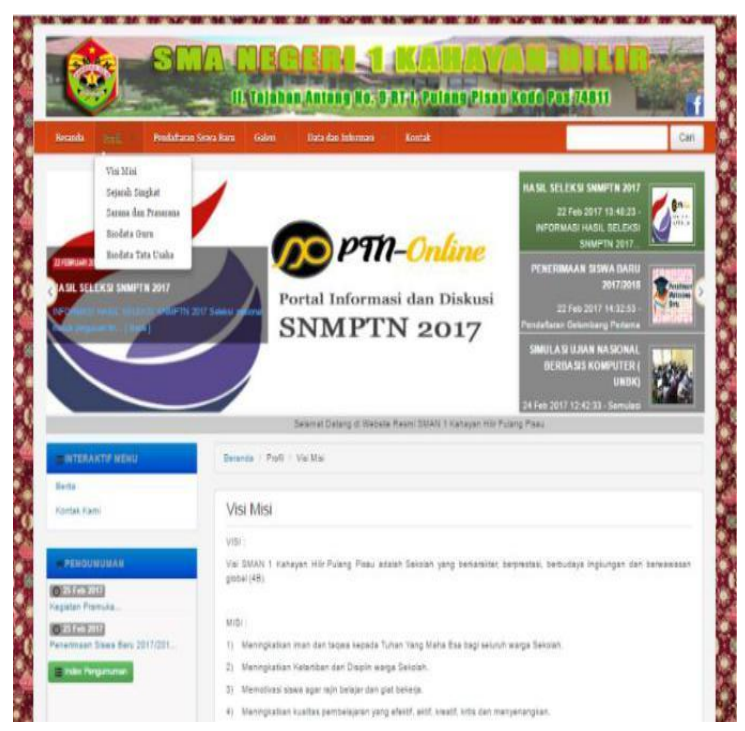

Gambar 2. Menu Angka

\section{Menu Galeri}

Pada menu galeri terdapat dua sub-menu yaitu galeri foto dan galeri video yang berisi foto-foto dan video kegiatan yang dilaksanakan oleh Sekolah SMAN 1 Kahayan Hilir Pulang Pisau. Dapat di lihat pada gambar 3.

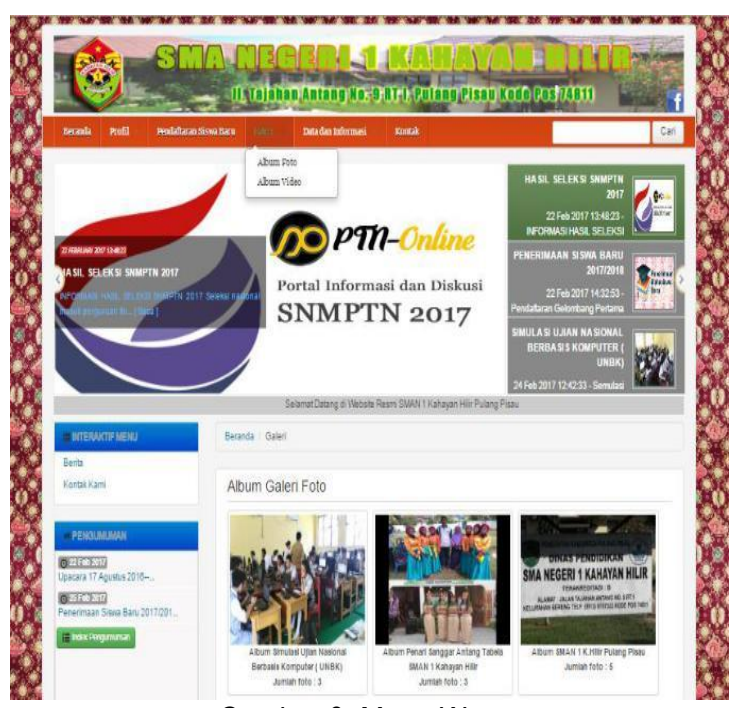

Gambar 3. Menu Warna

\section{Menu Data dan Informasi}

Pada menu data dan informasi terdapat empat sub-menu yaitu data informasi yang berisi agenda SMAN 1 Kahayan Hilir Pulang Pisau, sub-menu kedua menampilkan berita seputar Sekolah, submenu ketiga menampilkan pengumuman, dan sub- 


\section{Jurnal Sains Komputer dan Teknologi Informasi Page \\ E- ISSN: 2655-7460. Volume 2 Issue 2, Meí 2020 22 - 26}

menu keempat menampilkan download. Dapat di lihat pada gambar 4 .

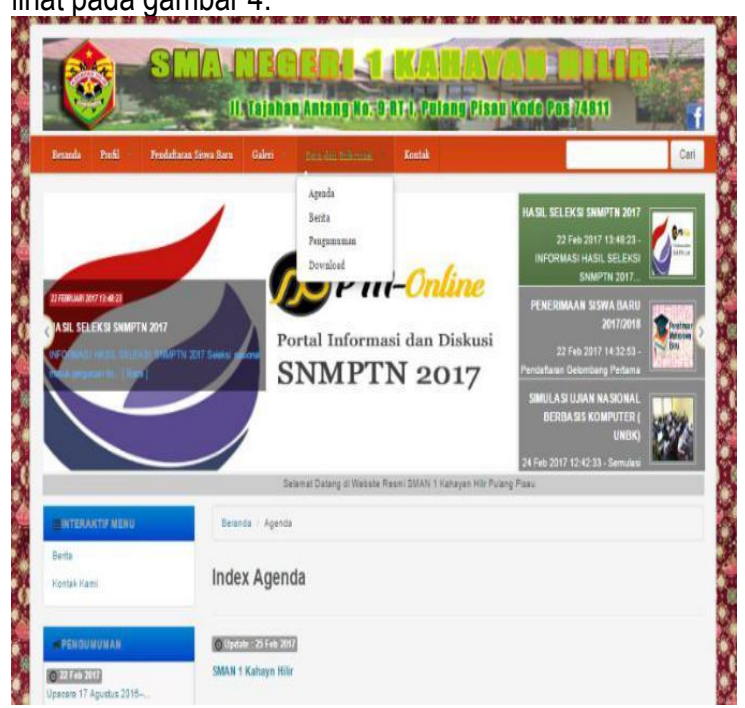

Gambar 4. Menu Data dan Informasi

\section{Menu Kontak}

Pada menu kontak berisi tentang informasi alamat kantor. Selain itu pada halaman ini pengunjung juga bisa mengisikan buku tamu. Dapat di lihat pada gambar 5 .

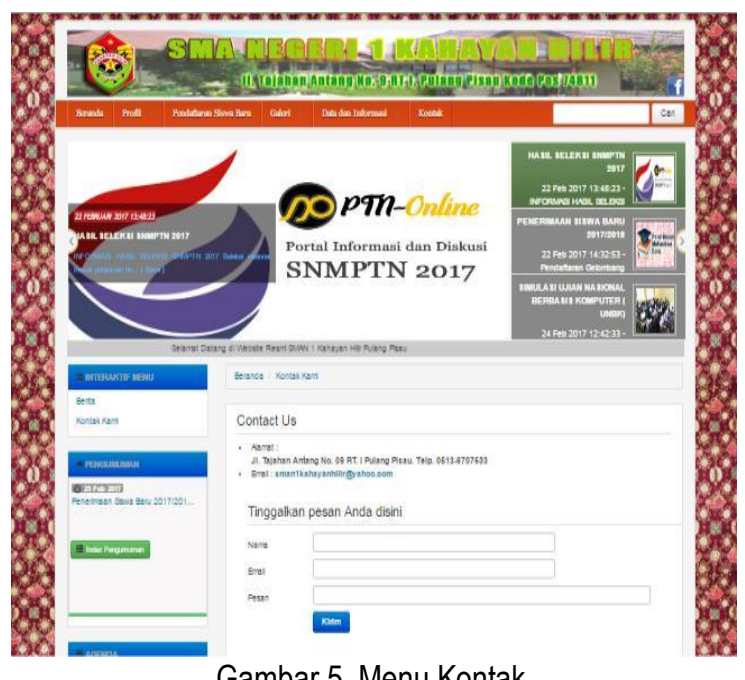

\section{Halaman Pendaftaran Siswa Baru}

Pada halaman pendaftaran ini sekolah menyediakan informasi terkait dengan pendaftaran untuk calon siswa baru yang ingin masuk sekolah SMAN 1 Kahayan Hilir Pulang Pisau. Sistem akan menampilkan pendaftaran bagi siswa baru yang ingin melakukan proses pendaftaran. Dapat di lihat pada gambar 6.

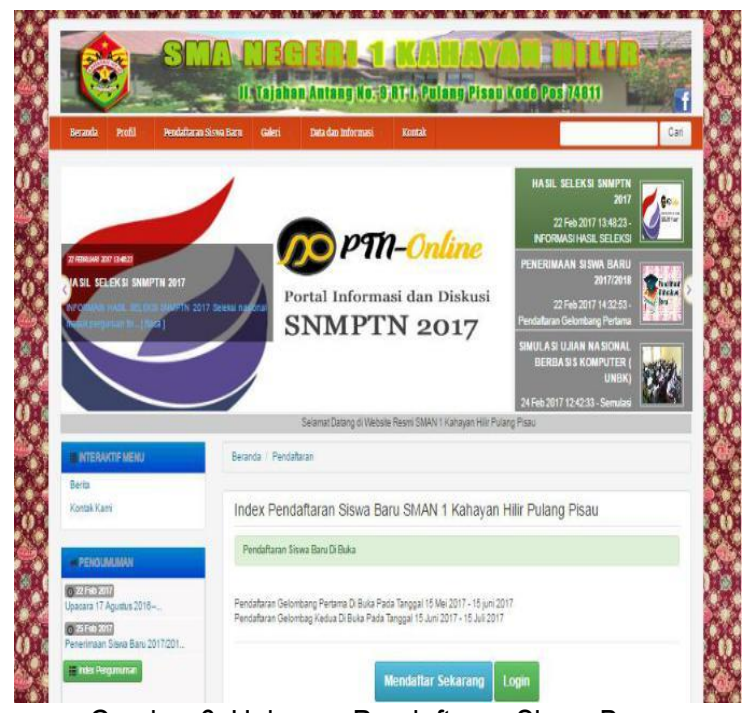

Gambar 6. Halaman Pendaftaran Siswa Baru

\section{Halaman Login Calon Siswa}

Pada halaman login calon siswa baru menyediakan form login berdasarkan data email dan password yang sudah calon siswa baru lakukan pada halaman register, selanjutnya jika siswa baru berhasil login maka akan ke halaman data pendaftaran calon siswa baru. Dapat di lihat pada gambar 7 .

\section{Selamat Datang di Halaman Pendaftaran Siswa Baru SMA Negeri 1 Kahayan Hilir Pulang Pisau}

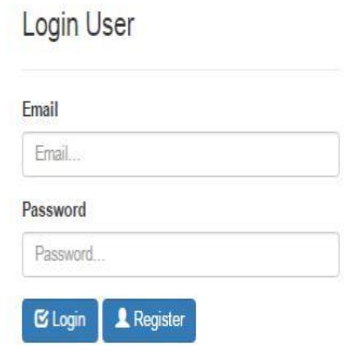

Bila Anda Belum Terdaftar, Silahkan Kik Register

Gambar 7. Halaman Login Calon Siswa

\section{Halaman Data Pendaftaran Calon Siswa Baru}

Pada halaman data pendaftaran ini sekolah menyediakan form pendaftaran untuk siswa baru yang ingin masuk sekolah SMAN 1 Kahayan Hilir Pulang Pisau. Sistem akan menampilkan form pendaftaran bagi siswa baru yang ingin melakukan proses pendaftaran. Dapat di lihat pada Gambar 8. 
Rosmiati dan M.Haris Qamaruzzaman. Sistem Informasi pada Sman i Kahayan Hilir 2020 Pulang Pisau Menggunakan Framework Codeigniter.

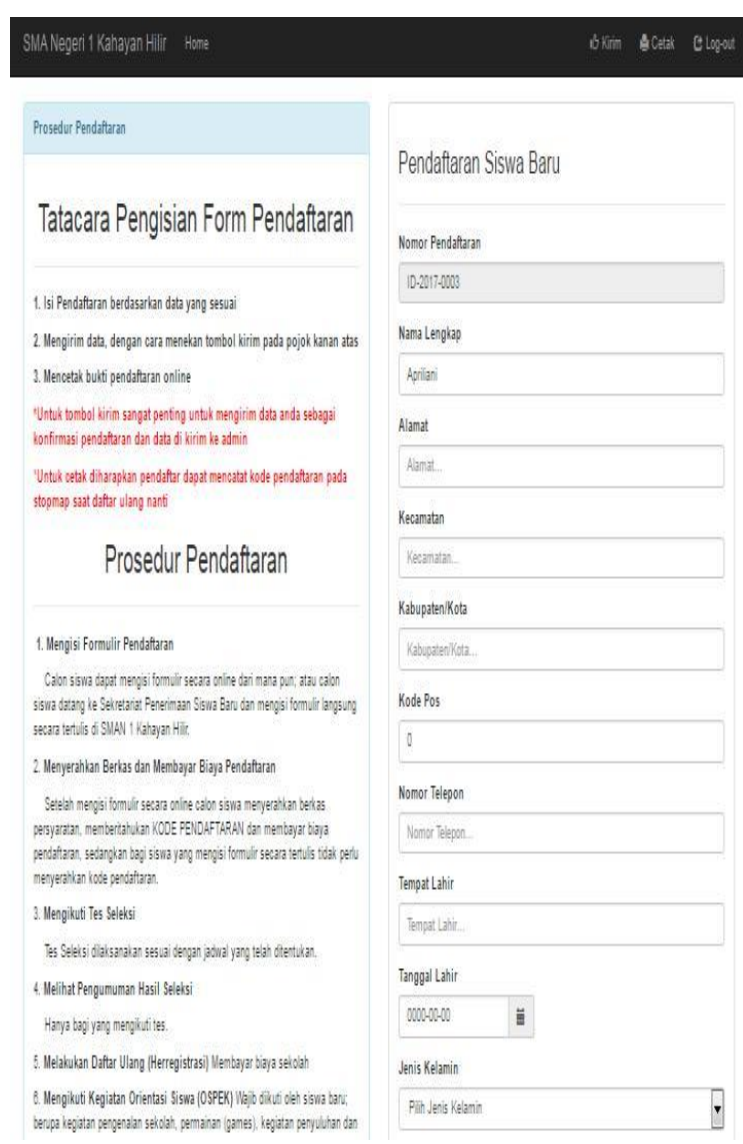

Gambar 8. Halaman Data Pendaftaran Calon Siswa Baru

\section{KESIMPULAN DAN SARAN}

\subsection{Kesimpulan}

1. Pada aplikasi website telah berhasil dibuat dengan menggunakan bahasa pemrogramman framework php dan alat bantu dalam program web yaitu jquery, XAMPP sebagai web server serta didukung pula dengan framework codeigniter dan twitter bootstrap sebagai pendukung untuk menerapkan web yang bisa diakses oleh komputer, laptop dan smartphone sesuai dengan perkembangan teknologi saat ini.

2. Dengan adanya aplikasi website ini pengguna (siswa, orang tua siswa serta masyarakat umum) dapat melihat atau mencari sebuah informasi yang berhubungan dengan Sekolah SMAN 1 Kahayan Hilir Pulang Pisau.
1. Dapat dikembangkan cara kerja sistem pada proses export data pendaftaran ke excel, agar lebih lengkap dan jelas.

2. Dapat menambah fitur-fitur pada website SMAN 1 Kahayan Hilir Pulang Pisau.

\section{DAFTAR PUSTAKA}

Aditya, N. A. 2011. Jago PHP \& MySQL, Dunia Komputer, Bekasi.

Arief, M. R. 2011. Pemrograman Web Dinamis Menggunakan PHP Dan Mysql, Andi, Yogyakarta.

Barokah, Muhammad. 2012. Rancang Bangun Aplikasi Berbasis Web pada SMK Yapemda 1 sebagai Sarana Pembelajaran dan Informasi, STMIK AMIKOM Yogyakarta.

Guritno, Suryo, Sudaryono dan Untung Rahrdja. 2010. Theory and application of IT Research Metodologi penelitian teknologi informasi. Andi Offset. Yogyakarta.

Hidayat, Rahmat 2010. Cara Praktis Membangun Website Gratis. Jakarta : PT Elex MediaKomputindo.

Nugroho, Adi. 2010. Rekayasa Perangkat Lunak Berorientasi Objek Dengan Metode USDP (Unified Software Development Process). Andi Offset. Yogyakarta.

Sam'ani. Annisa, S., Heri., 2018. Rancang Bangun Aplikasi Pengawasan Dan Pengendalian Komputer Laboratorium Multimedia STMIK Palangkaraya. Jurnal Sains Komputer dan Teknologi Informasi. Vol 1 Issue 1 e-ISSN 2655-7460. https://doi.org/10.33084/jsakti.v1i1.548

Siahaan, Daniel. 2012. Analisis Kebutuhan Dalam Rekayasa Perangkat Lunak. Andi Offset. Yogyakarta.

\subsection{Saran}

